\title{
Terapi Sistemik Defisit JKN: Bahan Refleksi Bagi Semua Pihak
}

\author{
Budi Hidayalt \\ Korespondensi:b_hidayat@hotmail.com
}

Dikirimkan pada 20 Juli 2016. Ditinjau pada 25 Juli 2016. Diterima pada 27 Juli 2016.

\begin{abstract}
Abstrak
Defisit layak disandang sebagai penyakit kronis JKN. Indikasi defisit terungkap dari angka rasio klaim. Pada tahun 2014 dan 2015 angka rasio klaim selalu berada diatas 100\%. Angka ini merupakan hasil pembagian biaya klaim (atau biaya kesehatan peserta) dengan pendapatan iuran. Dengan demikian rasio klaim menggambarkan penyerapan dana iuran untuk biaya kesehatan saja. Padahal pendapatan iuran juga harus dialokasikan untuk biaya operasional dan cadangan.

Defisit JKN akan terus bergulir jika terapi sistemik nihil. Untuk tahun 2016, hasil estimasi penulis dengan merujuk pada asumsi besaran iuran sesuai Peraturan Presiden No 28/2016 (Sekretariat Kabinet, 2016) dan tarif pelayanan Permenkes 59/2014 (Menteri Hukum dan Hak Asasi Manusia, 2014) menemukan angka rasio klaim 101\%. Artinya, pendapatan iuran masih kurang meski hanya untuk mendanai pelayanan kesehatan. Dari mana sumber dana untuk mendanai biaya operasional? Apakah JKN hanya mengandalkan suntikan dana pemerintah? Label penyakit kronis defisit layak disandang oleh JKN. Apa obatnya?
\end{abstract}

\section{Kata Kunci:}

Defisit, JKN, Evaluasi

1 Guru Besar FKMUI, dan Peneliti di Pusat Kajian Ekonomi dan Kebijakan Kesehatan, FKMUI 


\section{Kontrol Biaya Klaim}

Strategi pertama untuk mengerem defisit adalah mengontrol biaya klaim untuk memastikan klaim dibayar terhadap apa yang seharusnya dibayar. Secara matematis besaran biaya klaim dipengaruhi oleh nilai harga dan angka utilisasi layanan kesehatan. Untuk meredam biaya klaim maka dapat dilakukan dengan dua resep. Pertama adalah menurunkan harga layanan. Resep ini mudah dilakukan, cukup dengan merombak standar tarif pelayanan yang diatur Permenkes Nomor 59/2014 agar rasional terhadap pendapatan iuran. Namun jika opsi penurunan standar harga yang dipilih maka akan menuai masalah baru. Badai protes dari fasilitas kesehatan (faskes) akan datang silih berganti. Kualitas layanan menjadi terancam, meskipun pada produk kesehatan kualitas tidak selalu berbanding lurus dengan harga. Bahayanya, JKN akan menyandang gelar baru sebagai produk inferior. Ini yang harus dicegah.

Cara kedua mengontrol biaya klaim adalah mengendalikan utilisasi yang sifatnya abnormal. Jenis utilisasi ini tidak murni disebabkan oleh kebutuhan medis pasien, namun disebabkan oleh motif lain (target income) provider. Pencetus utilisasi abnormal adalah ketidakseimbangan informasi dan peran ganda provider. Ketika berobat, pasien umumnya tidak tahu terhadap jenis layanan kesehatan apa yang dibutuhkan. Pasien akan selalu menggantungkan pemilihan terapi atas saran provider yang memang lebih mengetahuinya. Sementara provider memiliki dua peran ganda (Blomqvist, 1991), yaitu sebagai penasehat atau advisor pasien dan penyedia jasa atau supplier layanan. Kedua peran ini melekat alamiah dan tidak bisa dipisahkan. Ketika tidak ada "polisi" yang mengontrol, atau sudah ada asuradur (missal BPJS Kesehatan) namun fungsi kontrolnya mandul maka kombinasi dari ciri asimetrik informasi dengan peran ganda provider melahirkan fenomena Supplier Induced Demand (SID) yang berujung pemborosan .

Fenomena SID mengglobal dalam praktik layanan kesehatan, dan terbukti empiris di banyak negara (De Jaegher and Jegers, 2000, Labelle et al., 1994, Carlsen and Grytten, 2000, Azzahrazade, 2016, Van Doorslaer and Geurts, 1987), termasuk Indonesia (Hidayat and Pokhrel, 2010, Azzahrazade, 2016). Analisis data Indonesian Family Life Survei mendeteksi fenomena SID di perkotaan yang memiliki tingkat kompetisi provider lebih tinggi dibandingkan di pedesaan (Hidayat and Pokhrel, 2010). Studi (Azzahrazade, 2016) dengan data Susenas dan Podes 2012 mengklarifikasi SID di Indonesia. Dari hasil analisis yang dilakukan dengan two-part (atau hurdle) model, Azahrazzade (2016) menemukan angka probabilitas dokter yang mendorong kunjungan pasien rawat jalan semakin tinggi seiring naiknya kompetisi dokter yang diukur dengan rasio dokter terhadap populasi.

Fenomena SID memang semakin menonjol ketika kompetisi provider semakin menguat (Léonard et al., 2009), dan terjadi dalam sistem kesehatan yang mengandalkan mekanisme pasar. Ini contoh anomali dari asumsi ekonomi yang menyatakan "kompetisi dan mekanisme pasar mendorong efisiensi”. Aplikasi asumsi ini pada kesehatan ternyata menelorkan hasil sebaliknya, inefisiensi. Ketika terjadi over-supply, misalnya, kondisi ekuilibrium penawaran dan permintaan pada pasar kesehatan terjadi bukan disebabkan oleh turunnya harga layanan sebagaimana asumsi ekonomi yang berlaku pada pasar non-kesehatan, namun karena kenaikan harga. Knsumen kesehatan tetap membelinya karena supplier (dokter) berperan tidak hanya sebagai penyedia jasa tetapi juga sebagai advisor.

Wujud konkrit SID bervariasi, tergantung dari pola bayar apa yang digunakan untuk membayar provider. Ketika pembayaran provider dilakukan dengan Diagnosis Related Groups (DRGs), wujud SID dapat berupa pemulangan dini pasien yang masih membutuhkan perawatan, 
atau bloody discharge (Qian et al., 2011) dengan harapan pasien berobat kembali. Bloody discharge juga terjadi akibat alokasi dana DRGs untuk perawatan pasien sudah terserap semua. Pada pelayanan rawat jalan, kaveat DRGs dapat berupa pemecahan kasus menjadi beberapa kunjungan yang mendorong lahirnya readmisi (Bjorvatn, 2013). Tidak heran jika DRGs, kecuali Indonesia, tidak lazim digunakan untuk membayar provider yang memberikan layanan rawat jalan. Altrnatifnya discount on charge yang digunakan di sejumlah negara, atau ambulatory payment classifications yang dipakai oleh program medicare di Amerika.

\section{Pemborosan}

Nihilnya pengendalian membuka peluang subur utilisasi abnormal yang berujung pemborosan. Adalah sistem jaminan kesehatan di Jerman yang menerapkan audit medis untuk menelisik rekam medis, minimal 10\% dari kasus klaim DRGs, yang diambil acak per tahun dari sejumlah rumah sakit sampel. Tujuannya untuk menilai apakah pasien jaminan memperoleh layanan kesehatan sesuai standar pelayanan, dan untuk mengklarifikasi apakah tagihan yang diajukan rumah sakit sejalan dengan diagnosis, serta jenis pelayanan yang diberikan oleh rumah sakit kepada pasien.

Di Indonesia, celah untuk meraih efisiensi terbuka lebar. Berapa triliun rupiah dana JKN yang bisa dihemat? Analisis data klaim INA-CBGs sampai bulan pembayaran Agustus 2015 menemukan 76\% klaim rawat jalan (atau 36 juta kasus) merupakan kasus-kasus readmisi. Memang tidak semua kasus readmisi tergolong bermasalah, namun ada sekitar 34\% (12.6 juta kasus) tergolong sebagai readmisi bermasalah dan diduga akibat motivasi SID. Dugaan SID diidentifikasi dengan kriteria jeda kunjungan pasien ke faskes sama untuk jenis penyakit yang sama antara kunjungan berikut dengan sebelumnya berada dalam rentang maksimal 7 hari. Nilai klaim atas kejadian readmisi dengan jeda antara kunjungan sebelum dan terakhir selama maksimal 7 hari mencapai Rp 5.1 triliun.

Selain pelayanan rawat jalan, utilisasi abnormal terdeteksi pula pada pemanfaatan rawat inap. Angka bloody discharge yang mendorong kejadian readmisi juga menyedot dana signifikan (mencapai 4\% dari total klaim rawat inap). Ada indikasi pula kasus klaim yang mengarah pada dugaan upcoding (Dafny, 2005, Berta et al., 2010) yang jika dihitung dampaknya terhadap biaya nilainya fantastis. Pembuktian empiris kasus-kasus upcoding harus dilakukan melalui audit medis.

Estimasi total biaya klaim INA-CBGs yang sudah dibayarkan oleh BPJS Kesehatan sampai dengan bulan pembayaran Agustus 2015 mencapai Rp 55,9 triliun. Seandainya saja readmisi dan SID pada pelayanan rawat jalan, serta dugaan praktik upcoding dan bloody discharge pada jenis pelayanan rawat inap terdeteksi oleh radar audit medis seperti halnya di Jerman, perhitungan penulis menemukan efisiensi dana mencapai sekitar $12.6 \%$ dari total klaim. Untuk itu, BPJS Kesehatan harus mengembangkan sebuah sistem yang sanggup untuk mendeteksi kasus-kasus tersebut. Algoritma sistem sangat mudah dikembangkan, dan cukup sederhana. Luaran dari sistem pendeteksian ini adalah basis data kasus-kasus klaim yang teridentifikasi bermasalah. Data ini selanjutnya digunakan sebagai dasar untuk menelusuri kasus klaim di lapangan dalam program audit medis. Dengan demikian, ketika melakukan aktivitas audit medis, para auditor tidak harus membokar jutaan klaim, namun cukup melacak kasus klaim yang sudah masuk dalam daftar bermasalah. Cara cerdas inilah yang harus dilakukan. 


\section{Efek Domino INA-CBGs}

Implikasi negatif INA-CBGs juga memberikan efek domino bagi penderitaan pasien dan sistem kesehatan. Rata-rata kunjungan berulang diantara pasien yang memanfaatkan layanan rawat jalan untuk kasus penyakit sama mencapai 4.7 per pasien. Dengan demikian readmisi berimbas tidak hanya pada pendanaan JKN tetapi juga pada pengeluaran pasien. Ketika berobat pasien sudah pasti mengeluarkan biaya transport. Biaya kesempatan, opportunity costs, pasien dan keluarga yang mendampinginya juga pasti lenyap. Penderitaan pasien semakin parah karena setiap mendatangi faskes menemui antrian sejak pendaftaran, pemanfaatan layanan sampai tahap pengambilan obat.

Penderitaan pasien juga tercermin oleh adanya kasus-kasus rujukan yang mengarah indikasi dumping (Ellis, 1998). Faskes cenderung memilih pasien yang menguntungkan saja, yakni menerima pasien yang dinilai akan menghabiskan biaya lebih rendah dari tarif INA-CBGs sementara pasien yang dinilai merugikan dirujuk ke faskes lain (Newhouse, 1989). Indikasi dumping ditelisik dengan menelusuri kasus-kasus rujukan horizontal, yaitu rujukan yang diberikan oleh perujuk faskes lanjut dengan tingkatan sama dengan faskes tujuan rujukan. Estimasi penulis menemukan angka dumping 33,7\% untuk rawat inap, dan 16\% untuk rawat jalan. Kejadian lempar-melempar pasien cenderung naik dari bulan ke bulan sejak implementasi JKN. Angka dumping rawat jalan naik dari 11,2\% pada bulan Januari 2014 menjadi 20,0\% pada Juli 2015 atau naik 78\% selama 18 bulan (4,3\% per bulan). Pada pelayanan rawat inap, kenaikan angka dumping selama periode yang sama mencapai $63 \%$ (3,5\% per bulan), naik dari 23,5\% pada Januari 2014 menjadi 38,5\% pada bulan Juli 2015. Meski dampak dumping relatif kecil pada efisiensi dana, fenomena ini berdampak negative bagi peserta yang menjadi objek dumping karena mereka akan dilempar dari satu faskes ke faskes lain. Ini akan menyebabkan ketidaknyamanan, dan jika dibiarkan akan berakumulasi pada ketidakpuasan peserta terhadap program JKN.

Efek domino implikasi negative INA-CBGs bagi overall sistem pelayanan kesehatan adalah terjadinya penumpukan dan antrian pasien. Pada kondisi ini yang selalu disalahkan adalah program JKN. Program ini dianggap tidak matang karena infrastruktur (supply, faskes) tidak dipikirkan sejak dini. Jika saja, misal, readmisi tidak terjadi, pasien cukup sekali datang ke faskes, dan faskes tersebut dapat digunakan oleh pasien lain. Karena proporsi kasus readmisi sangat tinggi, apalagi pada kasus rawat jalan, maka secara akumulasi menyebabkan kekurangan faskes. Rasio faskes dengan penduduk baik dari sisi nakes dan tempat tidur secara teoritis sudah cukup, namun praktiknya menunjukkan kekurangan yang terdeteksi dari fenomena antrian pasien, serta dan tidak adanya ruangan.

Tidak tersedianya ruang rawat inap bagi pasien JKN yang butuh pelayanan juga sering terdengar sejak implementasi JKN. Apakah ini memang murni disebabkan oleh tidak adanya ruangan atau karena fenomena dumping megingat banyak kasus pasien tidak jadi dirujuk ke faskes lain jika yang bersangkutan bersedia membayar layanan kesehatan sendiri. Disini dibutuhkan "polisi" untuk mengontrol praktik layanan kesehatan. Nihilnya kontrol akan menyebabkan pasien semakin terombang-ambing ketika mereka butuh pelayanan kesehatan. Dan cilakanya, JKN menjadi sasaran kesalahan.

\section{Genjot Pendapatan}

Strategi kedua untuk meredam defisit JKN dapat dilakukan dengan menggencot pendapatan JKN. Pendapatan dipengaruhi oleh besaran iuran dan jumlah peserta. Untuk itu, langkah siste- 
mik yang harus dilakukan adalah menaikkan nilai iuran. Sayangnya revisi iuran yang dituangkan dalam Peraturan Presiden 28/2016 (Sekretariat Kabinet, 2016) masih jauh berada dibawah nilai ideal. Tampak disini pemerintah ragu menjadikan JKN sebagai produk superior.

Cara kedua membenahi pendapatan adalah membangun tata kelola kepesertaan. BPJS Kesehatan tidak hanya focus mendorong jumlah peserta, tetapi harus memperhatikan pada kelompok mana prioritas harus dibidik sedini mungkin, serta bagaimana memastikan mereka konsisten membayar iuran. Sistem inilah yang harus dibangun. Rubah pola pikir atau mindset masyarakat untuk menyikapi klausul "wajib” dalam UU SJSN menjadi sebuah "kebutuhan". Mereka yang butuh tentunya akan berupaya memenuhi kebutuhannya. Sholat lima waktu adalah rukun Islam, dan kewajiban mutlak bagi kaum muslim. Seorang muslim yang taat akan selalu mengerjakan Sholat sebagai wahana dalam memenuhi kebutuhan melepas rindu untuk berjumpa dengan Allah. Ini contoh perubahan mindset kewajiban menjadi kebutuhan yang tampaknya perlu ditularkan bagi masyarakat Indonesia dalam menyikapi JKN. Sosialisasi dan edukasi publik terkait keberadaan dan seluk beluk JKN harus dilakukan terus menerus untuk membangun mindset tersebut.

\section{Intervensi Sistemik, Kumpulan PR}

JKN membutuhkan intervensi sistemik yang harus menembak pada sumber masalah defisit. Upaya menaikkan peserta tidak serta merta akan mampu meredam defisit JKN. Meskipun seluruh penduduk Indonesia masuk program JKN, dengan merujuk struktur tariff yang diatur Permenkes 69/2014 dan nilai iuran PerPres 28/2016, JKN akan tetap menyandang label penyakit kronis defisit karena kenaikan peserta secara proporsional tidak sebanding dengan kebutuhan biaya kesehatan per orang per bulan. Dengan demikian upaya kenaikan peserta harus dibarengi dengan upaya pengendalian, rasionalisasi harga layanan dan perbaikan nilai iuran. Ini paket sistemik untuk mentralisir defisit JKN.

Terkait intervensi pengendalian, JKN membutuhkan pelembagaan manajemen telaah utilisasi (utilization review) komprehensif untuk menjamin kualitas dan kontrol biaya. Aplikasi sistem informasi teknologi harus digunakan untuk mendeteksi kasus-kasus klaim yang bermasalah. Audit medis sebagai bagian dari aktivitas retrospektif telaah utilisasi untuk menelisik kasus-kasus klaim yang masuk dalam daftar hitam implikasi INA-CBGs (readmisi, bloody discharge, dan upcoding) juga harus dilakukan. Audit medis ini tentunya harus didukung oleh regulasi untuk memuluskan pelaksanaan ketika auditor membongkar berkas rekam medis pasien yang tersimpan disetiap faskes.

Selain intervensi sistemik diatas, dalam jangka panjang, permasalahan hulu terkait dengan skema pembayaran INA-CBGs, yakni klasifikasi penyakit, harus segera diselesaikan. Aplikasi DRGs, sejak INA-DRG (Jamkesmas) sampai INA-CBGs (JKN), belum pernah dilakukan evaluasi klasifikasi penyakit secara komprehensif yang digunakan sebagai dasar dalam pengelompokkan DRGs. Padahal ada sejumlah DRGs yang belum pernah muncul kasusnya. Atau kasus DRG sudah muncul, namun jumlahnya relatif kecil sehingga secara statistik tidak memadai digunakan dalam penentuan bobot tarif. Ini yang harus dituntaskan segera. Jika tidak, permasalahan tinggi/ rendahnya tariff pada kelompok DRGs tertentu dibandingkan dengan tariff rumah sakit akan tetap mengemuka sepanjang masa.

Inovasi metode pembayaran provider juga harus dibangun untuk menanggalkan kelemahan metode bayar yang digunakan dalam JKN. Inovasi potensialnya adalah bagaimana mengkombinasikan Kapitasi dan INA-CBGs dengan Pay-For-Performance. Apa indikator kinerja yang 
perlu digunakan untuk kemudian dilebur dalam skim Kapitasi dan INA-CBGs? Ini juga pekerjaan lanjutan yang harus difikirkan sedini mungkin.

\section{Kesimpulan}

Dari uraian dimuka, artikel ini menyimpulkan bajwa ada empat intervensi sistemik yang bisa dijalankan untuk meredam defisit: rasionalisasi harga, pelembagaan pengendalian, revisi nilai iuran, serta membangun manajemen kepesertaan. Keempat intervensi sistemik tersebut harus dilakukan simultan, serta melibatkan semua pelaku inti dalam program JKN.

Implementasi berbagai kebijakan yang terkandung dalam program JKN (missal reformasi pembayaran provider: Kapitasi dan INA-CBGs) tengah mendatangkan pekerjaan baru. Mempertahankan apa yang baik, dan berupaya terus untuk memperbaiki kelemahan adalah hal logis. Ini terjadi diseluruh dunia. Reformasi jaminan kesehatan tidak pernah berhenti. Maju dan benahi terus JKN. Rakyat BUTUH, jangan sampai mereka membencimu.

\section{Daftar Pustaka}

Azzahrazade 2016. Supplier Induced Demand on Outpatient Care in Indonesia: Analysis of National Social Economic Survey 2012. Faculty of Public Health, Universitas Indonesia, 1.

Berta, P., Callea, G., Martini, G. \& Vittadini, G. 2010. The effects of upcoding, cream skimming and readmissions on the Italian hospitals efficiency: A population-based investigation. Economic Modelling, 27, 812-821.

Bjorvatn, A. 2013. Hospital readmission among elderly patients. The European Journal of Health Economics, 14, 809-820.

Blomqvist, K. 1991. The doctor as double agent: Information asymmetry, health insurance, and medical care. Journal of Health Economics, 10, 411-432.

Carlsen, F. \& Grytten, J. 2000. Consumer satisfaction and supplier induced demand. Journal of Health Economics, 19, 731-753.

Dafny, L. S. 2005. How Do Hospitals Respond to Price Changes? American Economic Review, 95, 1525-1547.

De Jaegher, K. \& Jegers, M. 2000. A model of physician behaviour with demand inducement. Journal of Health Economics, 19, 231-258.

Ellis, R. P. 1998. Creaming, skimping and dumping: provider competition on the intensive and extensive margins 1. Journal of Health Economics, 17, 537-555.

Hidayat, B. \& Pokhrel, S. 2010. The Selection of an Appropriate Count Data Model for Modelling Health Insurance and Health Care Demand: Case of Indonesia. International Journal of Environmental Research and Public Health, 7, 9-27.

Labelle, R., Stoddart, G. \& Rice, T. 1994. A re-examination of the meaning and importance of supplier-induced demand. Journal of Health Economics, 13, 347-368.

Léonard, C., Stordeur, S. \& Roberfroid, D. 2009. Association between physician density and health care consumption: A systematic review of the evidence. Health Policy, 91, 121-134.

Menteri Hukum Dan Hak Asasi Manusia, R. I. 2014. Peraturan Menteri Kesehatan Nomor 59 Tahun 2014 Tentang Standar Tarif Pelayanan Kesehatan Dalam Penyelenggaraan Program Jaminan Kesehatan. Lembaran Negara Republik Indonesia Tahun 2014 Nomor 1287, 1-17.

Newhouse, J. P. 1989. Do unprofitable patients face access problems? Health Care Financing Review, 11, 33-42. 
Qian, X., Russell, L. B., Valiyeva, E. \& Miller, J. E. 2011. 'Quicker And Sicker' Under Medicare’s Prospective Payment System For Hospitals: New Evidence On An Old Issue From A National Longitudinal Survey. Bulletin of Economic Research, 63, 1-27.

Sekretariat Kabinet, R. I. 2016. Peraturan Presiden Republik Indonesia Nomor 28 Tahun 2016 Tentang Perubahan Ketiga Atas Peraturan Presiden Nomor 13 Tahun 2013 Tentang Jaminan Kesehatan. Lembaran Negara Republik Indonesia Tahun 2016 Nomor 62, 1-8.

Van Doorslaer, E. \& Geurts, J. 1987. Supplier-induced demand for physiotherapy in the Netherlands. Social Science \& Medicine, 24, 919-925. 